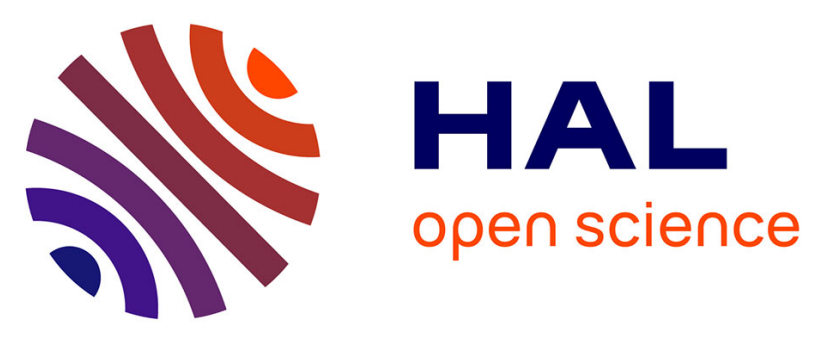

\title{
Transgenerational phenotypic plasticity of diapause induction and related fitness cost in a commercial strain of the parasitoid Aphidius ervi Haliday
}

Muhammad Mubashir Saeed, Kévin Tougeron, Abu Bakar Muhammad Raza, Muhammad Afzal, Anjum Aqueel, Guillaume Jean Le Goff, François Renoz, Jennifer Pirotte, Thierry Hance

\section{To cite this version:}

Muhammad Mubashir Saeed, Kévin Tougeron, Abu Bakar Muhammad Raza, Muhammad Afzal, Anjum Aqueel, et al.. Transgenerational phenotypic plasticity of diapause induction and related fitness cost in a commercial strain of the parasitoid Aphidius ervi Haliday. Insect Science, 2020, 10.1111/1744-7917.12794 . hal-02939810

HAL Id: hal-02939810

https://hal-univ-rennes1.archives-ouvertes.fr/hal-02939810

Submitted on 15 Sep 2020

HAL is a multi-disciplinary open access archive for the deposit and dissemination of scientific research documents, whether they are published or not. The documents may come from teaching and research institutions in France or abroad, or from public or private research centers.
L'archive ouverte pluridisciplinaire HAL, est destinée au dépôt et à la diffusion de documents scientifiques de niveau recherche, publiés ou non, émanant des établissements d'enseignement et de recherche français ou étrangers, des laboratoires publics ou privés. 
Author running head: M. M. Saeed et al.

Title running head: Maternal effects, diapause and life-history traits

Correspondence: Thierry Hance, Earth and Life Institute, Biodiversity Research Centre,

Université catholique de Louvain, Louvain-la-Neuve, Belgium. Email:

thierry.hance@uclouvain.be

\title{
ORIGINAL ARTICLE
}

\section{Transgenerational phenotypic plasticity of diapause induction and related fitness cost in}

\section{a commercial strain of the parasitoid Aphidius ervi Haliday}

Muhammad Mubashir Saeed ${ }^{1,2}$, Kévin Tougeron ${ }^{2}$, Abu Bakar Muhammad Raza ${ }^{1}$, Muhammad Afzal $^{1}$, Anjum Aqueel ${ }^{1}$, Guillaume Jean Le Goff ${ }^{2}$, François Renoz ${ }^{2}$, Jennifer Pirotte $^{2}$ and Thierry Hance ${ }^{2 *}$

${ }^{1}$ Department of Entomology, University College of Agriculture, University of Sargodha, Sargodha, Pakistan;

${ }^{2}$ Earth and Life Institute, Biodiversity Research Centre, Université catholique de Louvain, Louvain-la-Neuve, Belgium;

\begin{abstract}
Diapause is an adaptation that insects have evolved to synchronize their life cycle with that of seasonal climatic changes and resources availability. However, cues for its induction are not always clear and, in some cases, a maternal effect may be involved. At the population level,
\end{abstract}

This is an Accepted Article that has been peer-reviewed and approved for publication in the Insect Science but has yet to undergo copy-editing and proof correction. Please cite this article as doi: 10.1111/1744-7917.12794.

This article is protected by copyright. All rights reserved. 
just a part of the individuals may exhibit diapause with important consequences in terms of winter survival. Moreover, clear indicators of diapause state are difficult to identify. Diapause induction was thus investigated in the aphid parasitoid species Aphidius ervi Haliday (Hymenoptera: Braconidae) developing in the aphid Sitobion avenae (Hemiptera: Aphididae) at four crossed photo-thermal regimes $\left(16{ }^{\circ} \mathrm{C}\right.$ and $8{ }^{\circ} \mathrm{C}, 16: 8 \mathrm{~h} \mathrm{~L}: \mathrm{D}$ and $\left.8: 16 \mathrm{~h} \mathrm{~L}: \mathrm{D}\right)$, and during 2 successive generations. We analyzed the reliability of changes in mummy color to assess for the diapausing state compared to dissections, and we measured parasitoid morphological and physiological traits. We observed that the proportion of dark brown mummies increased after one generation under low photothermal regime compared to other regimes. No diapause was recorded at $16^{\circ} \mathrm{C}, 16: 8 \mathrm{~h} \mathrm{~L}: \mathrm{D}$, while we observed $16.2 \%$ and $67.5 \%$ diapause incidence at $8^{\circ} \mathrm{C}, 8: 16 \mathrm{~h} \mathrm{~L}: \mathrm{D}$, at 1 st and 2 nd generation, respectively. Diapause induction is thus increased by short day-length conditions and low temperatures as well as by maternal effects. All parasitoid life-history traits (weight, size, fat content, water content, egg-load and longevity) were affected by the photo-thermal regime and/or the generation. These results raise new questions on the environmental thresholds needed to induce diapause and on survival and adaptation potential of commercially available parasitoid strains in different environments.

Key words dormancy; life history traits; mummy color; photo-thermal regimes; transgenerational plasticity

\section{Introduction}

Adaptive phenotypic plasticity allows organisms to respond to environmental changes at different times of their life-cycle (Sinclair et al., 2003; Pigliucci, 2006). As temperature is 
one of the main factors affecting ectotherms development and activity (Hallman \& Denlinger, 2019), facultative diapause has evolved as a particular type of developmental phenotypic plasticity. Winter diapause is usually induced by well-defined environmental cues, such as a photoperiod and temperature decrease, that precede the arrival of unfavorable conditions (Tauber et al., 1986). It is distinguished from quiescence which is a direct and short-term response to stressful conditions (Tauber et al., 1986).

In temperate areas, the proportion of individuals that undergo diapause increases as the time left for growth and development before the arrival of harsh conditions becomes limited. However in a population, not all the individuals will respond to environmental cues inducing diapause with the same intensity (i.e., at the same threshold), resulting in reaction norm variability among genotypes (Bradford \& Roff, 1993; Hopper, 1999). In temperate climates most aphid parasitoids arrest their growth or activity before winter time and lie dormant inside the dead host cuticle (Langer \& Hance, 2000; Polgár \& Hardie, 2000). However, among parasitoids associated with anholocyclic cereal aphids under mild winter only a proportion of the population undergoes true diapause, the other part can remain active during winter if climatic conditions allow these parasitoids to terminate their development (Polgár et al., 1995; Langer \& Hance, 2000; Tougeron et al., 2017b).

The recent work of Andrade et al. (2016) showed that the increase in average winter temperatures could change the composition of parasitoid communities in cereal crops probably because some species undergo changes among the proportions of individuals which enter diapause. A rapid shift in aphid-parasitoid communities was observed in Western France over the last three decades due to modifications in overwintering strategies of insects (Tougeron et al., 2018a) and of top-down and bottom-up effects (Chidawanyika et al., 2020), reflecting the loss of diapausing stage by some species, or at least indicating that conditions 
for diapause induction are no longer encountered. Some parasitoid strains show low levels of diapause, either because they have been maintained in constant summer-like rearing conditions (e.g., commercially available strains), because they have evolved with very mild or no winter conditions in their area of origin, or because of adaptation to climate-warming (Gariepy et al., 2015; Tougeron et al., 2019).

The aphid parasitoid Aphidius ervi (Hymenoptera: Braconidae) is a generalist parasitoid of aphids which can be found in numerous cultivated crops around the world and in which commercial strains are also available for biological control (Van Emden \& Harrington, 2017). In $A$. ervi, diapause occurs at the prepupae instar inside the aphid host cuticle (called a "mummy"). In this species, continuous exposure to $15^{\circ} \mathrm{C}$ at a photoperiod of 9 : $15 \mathrm{~h} \mathrm{~L}: \mathrm{D}$ (Light : Dark) for three consecutive generations produced an increase in the number of diapausing individuals up to a maximum of $42.2 \%$ (Langer \& Hance, 2000). In addition to direct perception of environmental cues by the diapausing generation, these results imply the existence of a maternal effect. Such transgenerational effects in which conditions perceived by one generation induce diapause in the following generation have already been described in numerous other species such as in mosquitoes (Lacour et al., 2014) or fly parasitoids (Saunders, 1965). In the case of $A$. ervi, a previous paper suggested that diapause levels and life-history traits can be modulated by conditions experienced by precedent generations, due to transgenerational plasticity (TGP) (Tougeron et al., 2020). Among other mechanisms, TGP can involve epigenetics (Jablonka \& Raz, 2009), which is known to act on phenotypic expression, including diapause (Reynolds, 2017). Acclimation within and across generations is generally thought to be adaptive for insects (Basson et al., 2012). Adaptive acclimation effects through TGP on overwintering strategies have been 
shown in overwintering insects, such as in the grain aphid Sitobion avenae (Hemiptera: Aphididae) (Powell \& Bale, 2008).

Life-history traits are also subject to phenotypic plasticity (Travis, 1994) and their expression can be influenced by diapausing states or to diapause-inducing cues. If diapause is adaptive to face adverse conditions, it also represents a fitness cost in term of survival of diapausing stages and for emerging adults (Hance et al., 2007). For instance, the parasitoid Asobara tabida showed a negative relationship between the time spent in diapause and egg load in adults (Ellers \& Van Alphen, 2002). For the aphid parasitoid Praon volucre Haliday, diapause is also associated with a reduction of adult longevity (Colinet et al., 2010). In that case, diapausing mummies present a higher lipid mass than non diapausing ones. This storage of lipids could be used both to ensure survival during a long period of diapause but also as energy resources for the production of eggs after diapause. We can therefore expect exacerbated trade-offs between survival and fertility as shown for $A$. tabida (Ellers \& Van Alphen, 2002), or between lipid storage and diapause (Varpe \& Ejsmond, 2018). Moreover, costs also arise from the need to resist cold exposure during overwintering (Langer \& Hance, 2000; Hodkova \& Hodek, 2004). Thus fitness related traits (e.g., female fecundity) may be affected either by cold storage or by diapause itself, even over several generations (Ellers \& Van Alphen, 2002; Levie et al., 2005). Life-history traits such as fecundity, survival, size, energetic reserves and developmental time are therefore usually measured to evaluate parasitoid fitness (Godfray, 1994; Roitberg et al., 2001) and consequence of cold exposure or diapause (Colinet et al., 2010; Ismail et al., 2013).

Within insect populations that need to overwinter, color polymorphism has been commonly reported (Leather et al., 1995). In the case of $A$. ervi, mummies have been described as light brown, intermediate and dark brown. Previous research stated that dark 
brown mummies usually correspond to a state of diapause (Brodeur \& McNeil, 1989b; Krespi et al., 1994; Polgár et al., 1995; Langer \& Hance, 2000). In another aphid parasitoid, Praon volucre, dark colored mummies are always correlated to a significant delay/arrest in development of the parasitoid with also significant reduced metabolic rates whose are characteristic of diapausing insects (Colinet et al., 2010). However, in a related species Aphidius rhopalosiphi, mummy color characteristics was not found as a reliable marker for identifying diapause and is most probably a phenotypic variation only linked to cold resistance (Legrand et al., 2004b, c). In consequence, plasticity in the color of the parasitized mummy seems to be very species-specific, must be taken with caution when considering diapause indicators and must be completed with other, more reliable methods such as mummy dissections.

In this study, we aimed to test whether diapause levels could vary depending on the photothermal regime and how this effect can be amplified during successive generations of a commercial strain of the parasitoid A. ervi. Entering diapause under spring-like or summerlike conditions should be avoided because of expected costs, unless competition is too high (Tougeron et al., 2017a). Transgenerational plasticity (acclimation) in response to environmental cues might be expressed because it should be adaptive and have benefits regarding fitness. Plastic response allows rapid responses to changing conditions and it is this aspect we want to test over a very small number of generations. We explored mummy coloration patterns and emergence delays as indicators of the state of diapause. Moreover, we evaluated how photo-thermal regimes could influence the value of a set of fitness-related parasitoid life-history traits. We hypothesized that low temperatures and photoperiods would increase the number of diapausing parasitoids, and that diapause levels would be higher at the second generation experiencing such conditions. We also predicted that fitness would be 
reduced at low temperature and short photoperiod, due to the physiological costs induced by these conditions.

\section{Materials and methods}

\section{Biological material and insect rearing}

Cereal aphids Sitobion avenae (Aphididae: Hemiptera) were obtained from Koppert (The Netherland), and they were maintained on wheat seedlings (Triticum aestivum L.) in 0.3 $\mathrm{m}^{3}$ cages under laboratory conditions $\left(18{ }^{\circ} \mathrm{C}, 16: 8 \mathrm{~h} \mathrm{~L}: \mathrm{D}, 65 \% \pm 5 \%\right.$ relative humidity). Parasitoids $A$. ervi were purchased from Viridaxis S.A. (Belgium) and reared on S. avenae under the same laboratory conditions. The experiment was conducted in the laboratory of Earth and life Institute, Biodiversity Research Centre, Université catholique de Louvain, Belgium.

We checked for the presence of the facultative endosymbionts Hamiltonella defensa, Serratia symbiotica and Regiella insecticola in our aphid culture because their presence could affect parasitism rates and diapause (Douglas, 1998; Mushegian \& Tougeron, 2019). The infection status was verified using diagnostic PCRs with primers 16SA1 (5'AGAGTTTGATCMTGGCTCAG-3') and PASS cmp (5'-GCAATGTCTTATTAACACAT3') (Fukatsu et al, 2000; Attia et al., 2016). None of the facultative symbionts we tested were found in our aphid clone.

\section{Parasitism and photo-thermal regimes}

Parasitoid females used in the experiment were less than $48 \mathrm{~h}$ old and naive. In order to ensure mating, each female was maintained for $24 \mathrm{~h}$ at $18^{\circ} \mathrm{C}$ with 1 male in an Eppendorf tube $(1.5 \mathrm{~mL})$ and fed with $50 \%$ honey solution. After mating, each female was presented a 
batch of 10 aphids $S$. avenae (3-4 days old, L2 instar) in a glass petri dish $(\varnothing 4.5 \mathrm{~cm})$ and stings were observed directly. Once parasitized, batches of 10 aphids were removed from the petri dish and transferred to a 4-6 days old fresh wheat seedlings cultured in glass vials (centrifuge tube $50 \mathrm{~mL}$ ). The top of glass vial was closed by mesh cloth for ventilation. Diapause induction, developmental delay and life-history traits of $A$. ervi were analyzed under four crossed photo-thermal regimes; 2 temperature regimes $\left(8^{\circ} \mathrm{C}\right.$ and $\left.16^{\circ} \mathrm{C}\right)$ and 2 photoregimes (16:8 h L : D and $8: 16 \mathrm{~h} \mathrm{~L}: \mathrm{D})$, over 2 consecutive generations. These conditions match the range of temperatures and photoperiod parasitoids encounter in the field in Belgium at the end of autumn and induced diapause in a related species Aphidius rhopalosiphi (Legrand et al., 2004a; Tougeron et al., 2017b). Parasitized aphids were distributed in four different incubators and were kept at these conditions until mummy formation and adult emergence, following the protocol of Tougeron et al. (2019b). For each photo-thermal regime and generation, 200 aphids were parasitized (by 20 different females) and we managed to obtain between 80 and 191 mummies. After measuring the desired parameters on the $1^{\text {st }}$ parasitoid generation, the 2 nd generation was obtained from parents that experienced the same treatment in the same way as described above.

\section{Diapause induction, development time and mummy coloration}

Mummies were kept upon formation separately in small plastic tubes under their respective photo-thermal regimes. Mummies were characterized as light brown, intermediate and dark brown following the categories described in previously published work (Colinet et al., 2010) and presented in Figure 1.

Day-degrees necessary for an individual insect's development was calculated from developmental time of egg laying to mummy formation and after mummy formation to 
development of adult at different photo-thermal regimes for 2 generations. Developmental time on a day-degree (DD) time scale was calculated as: $\mathrm{DD}=\mathrm{DT}\left(\mathrm{T}-\mathrm{T}_{\mathrm{o}}\right)$, where $\mathrm{DT}$ is the

calculated developmental time in days, $\mathrm{T}$ is the temperature in ${ }^{\circ} \mathrm{C}$, and $\mathrm{T}_{\mathrm{o}}$ is the threshold temperature for development of $A$. ervi, which is $2.2^{\circ} \mathrm{C}$ (Sigsgaard, 2000). We also measured mummy formation date, time from egg-laying to emergence and time from mummy formation to parasitoid emergence.

Parasitoids which did not emerged 3 weeks after mummy formation were shifted to $16^{\circ} \mathrm{C}$. If they did not emerged after 3 more weeks (total of 6 weeks), mummies were dissected to determine if they contained alive larvae still in the state of diapause or dead ones (Colinet et al., 2010; Tougeron et al., 2017b). In that case, after dissection, alive larvae were considered to be under diapause as the delay of emergence was over three weeks once placed at $16^{\circ} \mathrm{C}$ for which quiescence should be naturally interrupted to continue development. This helped to test the reliability of the diapause identification method based on the coloration of the mummy.

\section{Trait measurements}

We measured success of emergence, adult longevity, fecundity, and sex ratio at each photo-thermal regime and for each generation. For survival, 20 male and 20 female parasitoid adults were individually placed in Eppendorf tube $(1.5 \mathrm{~mL})$ and fed with a $50 \%$ honey solution at $20^{\circ} \mathrm{C}$, as done by Levie et al. (2005), and for each treatment. Survival of each adult parasitoid was monitored twice a day until the last parasitoid died. To measure potential fecundity of $A$. ervi, $<24 \mathrm{~h}$ emerged females were freeze-killed at $-20^{\circ} \mathrm{C}$ and dissected $(n=20$ for each treatment) and the number of eggs at emergence was counted as described by Lins et al. (2013). 
For morphological traits, 40 additional one-day-old adult parasitoids (20 males and 20 females) were killed by cold exposure at $-20^{\circ} \mathrm{C}$ for 10 minutes and we then measured size, fresh mass, dry mass, fat mass, and fat contents (Ismail et al., 2010), for each treatment. Fresh mass was measured using a Mettler-electrobalance Me22 (sensitivity: $1 \mu \mathrm{g}$ ). Size was measured using the length of the left hind tibia as a standard estimation for aphid parasitoids (Godfray, 1994; Ismail et al., 2012). Digital pictures of hind tibia were captured with Nikon 4500 camera mounted on a stereomicroscope. The images captured were analyzed by ImageJ v. 1.48 software (Wayne Rasband, USA). The dry mass was measured after the samples/adults were oven dried for 3 days at $60^{\circ} \mathrm{C}$. Each sample was left in Eppendorf tube containing $1 \mathrm{~mL}$ of extracting solution (chloroform : methanol solution $2: 1$ ) on agitator for 2 weeks (Terblanche et al., 2004; Colinet et al., 2006). Adults were then placed in an air oven for $12 \mathrm{~h}$ at $60^{\circ} \mathrm{C}$ to eliminate residues of the extracting solution and to obtain the lean dry mass. Fat mass and fat contents were calculated using the formulas:

Fat mass $=$ Dry mass - Lean dry mass

Fat contents $=$ Fat mass $/$ Lean dry mass

following Terblanche et al. (2004), Colinet et al. (2006).

Water mass was determined as the difference between fresh and dry mass. The water content (WC) was calculated as a proportion of dry mass using the formula:

Water Content $=$ Water mass/ Dry mass

following Colinet et al. (2006)

\section{Statistical analyses}

Coloration patterns were compared among generations and photothermal regimes using a chi-square test of independence, by considering the numbers of dark vs. white 
mummies for each tested condition. Intermediate coloration forms were ignored in this analysis but were counted and displayed in the graphic representation. This was done to analyze the differences in proportions of the two most contrasted colorations (dark vs. white). Emergence patterns were fitted to a survival logistic-rank model (using package survival) by adding a censoring factor for non-emerged living parasitoids inside mummies. The effects of the generation, of the photoperiod and the temperature regimes, as well as their three-way interaction were considered and models were tested using Wald chisquares using the Anova function of the package car (Fox \& Weisberg, 2011). Life-history trait data were compared among generations, photoperiod and the temperature regimes and their three-way interaction using GLMs with gaussian distribution and tested using a likelihood-ratio chisquare method (Fox \& Weisberg, 2011). However, biological interpretation could not be made on two-way interactions of photoperiod and temperature with generation, because parasitoids from G2 are necessarily coming from the same photoperiod $\mathrm{x}$ temperature regime as those of G1. Tukey's HSD posthoc tests were performed to differentiate means. Previous work with similar experimental design on the same species did not find any "brood" effect, so all female lines and families were treated equally (Tougeron et al., 2020). Statistical analyses were performed using R (R Core Team, 2019).

\section{Results}

\section{Mummies characteristics}

The percentage of brown colored mummies (individuals usually considered under diapause or dormant state) increased from generation 1 to generation 2 , all regimes put together (Fig. $2, \chi^{2}=84.542, \mathrm{df}=1, P<0.001$ ), and it also increased at photoregimes under low photoperiod ( $8: 16 \mathrm{~h} \mathrm{~L}: \mathrm{D})$ (Fig. $2, \chi^{2}=162.87$, df $\left.=3, P<0.001\right)$. At least $72 \%$ of the 
mummies were brown at the second generation of the most stringent regime of $8^{\circ} \mathrm{C} 8: 16 \mathrm{~h}$ L : D (Fig. 2).

Emergence delay

Emergence patterns were significantly affected by the photoperiod $\left(\chi^{2}=350.4, \mathrm{df}=1\right.$, $P<0.001)$, the temperature regime $\left(\chi^{2}=773.9\right.$, df $\left.=1, P<0.001\right)$, and were different between generations $\left(\chi^{2}=286.96, \mathrm{df}=1, P<0.001\right)$. There was an interaction effect between photoperiod and temperature $\left(\chi^{2}=157.2 \mathrm{df}=1, P<0.001\right)$ but also between photoperiod and generation $\left(\chi^{2}=55.6\right.$, df $\left.=1, P<0.001\right)$, meaning that the photoregime did not affect development time in the same way depending on the considered generation (Fig. 3). Overall, parasitoids took longer to develop at the second generation than at the first one $(10.05 \pm 0.43$ days vs. $5.98 \pm 0.26$ days, respectively). Parasitoids also took longer to develop at $8^{\circ} \mathrm{C}, 8: 16$ $\mathrm{h} L: \mathrm{D}(15.66 \pm 0.84$ days $)$ than at all of the other regimes $(4.12 \pm 0.10,5.61 \pm 0.22$ and 6.82 \pm 0.19 days for $16^{\circ} \mathrm{C}, 16: 8 \mathrm{~h} \mathrm{LD}, 16^{\circ} \mathrm{C}, 8: 16 \mathrm{~h} \mathrm{LD}$ and $8^{\circ} \mathrm{C}, 16: 8 \mathrm{~h} \mathrm{~L}: \mathrm{D}$, respectively).

At $16^{\circ} \mathrm{C}$, all parasitoids from the 180 mummies emerged within three weeks, while a proportion of the mummies did not emerge at $8^{\circ} \mathrm{C}$, especially for the second generation placed at $8^{\circ} \mathrm{C}, 8: 16 \mathrm{~h} \mathrm{~L}: \mathrm{D}$ (up to $67.5 \%$ ) (Table 1). Out of both photoregimes at $8^{\circ} \mathrm{C}, 123$ (38 during 1st generation and 85 during 2nd generation) parasitoids did not emerged from their mummies after 3 weeks. After being shifted to $16^{\circ} \mathrm{C}, 52$ parasitoids emerged rapidly, 39 parasitoids were found dead and 32 were still alive at the prepupae instar after three other weeks. Parasitoids that were found alive after mummy dissection were considered as diapausing individuals. Diapause levels reached $1.2 \%$ and $1.5 \%$ at $8^{\circ} \mathrm{C}, 16: 8 \mathrm{~h} \mathrm{~L}: \mathrm{D}$ (for G1 and $\mathrm{G} 2$, respectively) and $4.7 \%$ and $23.8 \%$ at $8^{\circ} \mathrm{C}, 8: 16 \mathrm{~h} \mathrm{~L}: \mathrm{D}$ (for $\mathrm{G} 1$ and $\mathrm{G} 2$, respectively) (Table 1). All the mummies that were dissected and in which a diapausing parasitoid was found were brown in colour.

This article is protected by copyright. All rights reserved. 
At the first generation, emergence peaks occurred at day 3, 4, 5 and 5, with 72, 52, 41 and 33 parasitoids, respectively, at $16^{\circ} \mathrm{C}, 16: 8 \mathrm{~h} \mathrm{~L}: \mathrm{D}, 16^{\circ} \mathrm{C}, 8: 16 \mathrm{~h} \mathrm{~L}: \mathrm{D}, 8^{\circ} \mathrm{C}, 16: 8 \mathrm{~h} \mathrm{~L}$ : $\mathrm{D}$ and $8^{\circ} \mathrm{C}, 8: 16 \mathrm{~h} \mathrm{~L}: \mathrm{D}$, respectively. At the second generation, emergence peaks occurred at day 4 , day 7 , day 6 and day 18 , with $35,28,25$ and 10 parasitoids, respectively, at $16^{\circ} \mathrm{C}$, $16: 8 \mathrm{~h} \mathrm{~L}: \mathrm{D}, 16^{\circ} \mathrm{C}, 8: 16 \mathrm{~h} \mathrm{~L}: \mathrm{D}, 8^{\circ} \mathrm{C}, 16: 8 \mathrm{~h} \mathrm{~L}: \mathrm{D}$ and $8^{\circ} \mathrm{C}, 8: 16 \mathrm{~h} \mathrm{~L}: \mathrm{D}$, respectively (Fig. 3).

Results revealed that day-degrees for egg-to-mummy formation were the highest at $8^{\circ} \mathrm{C}, 8: 16 \mathrm{~h} \mathrm{~L}: \mathrm{D}$, whereas lowest day-degree requirements were recorded at $16^{\circ} \mathrm{C}, 16: 8 \mathrm{~h}$ LD. For mummy-to-adult duration, highest day-degree requirement was observed at $16^{\circ} \mathrm{C}, 8$ : $16 \mathrm{~h} \mathrm{~L}: \mathrm{D}$, while lowest day-degrees requirement was observed at $8^{\circ} \mathrm{C}, 16: 8 \mathrm{~h} \mathrm{~L}: \mathrm{D}$, for both generations (Table 2).

\section{Life-history traits}

There were significant differences in mean value of most of the measured life-history traits among photoperiod, temperature regimes, generations, with interaction effects of these factors (GLMs, Table 3, Table 4). For all traits but fat mass, there were significant interaction effects of photoperiod and temperature, meaning that the effect of photoperiod depended on the tested temperature, and reversely (Table 3). No generation effect was found on tibia size, dry weight and water content. Overall and all photoregimes put together, mean trait value of all other traits and longevity of both males and females were higher for the first than for the second generation. Egg-load was the only trait that was observed higher at the second generation. The effect of generation on fresh weight and longevity of both males and females was different depending on the photo-thermal regime tested (thee-way interaction effect). For both generations, mean trait values were overall different among regimes at $16^{\circ} \mathrm{C}$ and regimes at $8^{\circ} \mathrm{C}$, although complex interactions were observed (Table 4). 
Noticeably, during the $2 \mathrm{nd}$ generation at $8^{\circ} \mathrm{C}, 8: 16 \mathrm{~h} \mathrm{~L}: \mathrm{D}$, minimum fresh weight $(0.15 \mathrm{mg})$ was recorded. This very low value of fresh weight also corresponds to very low values of dry weight, tibia size and fat-content. Sex-ratio was male-biased for most of the treatments, especially at $8^{\circ} \mathrm{C}, 8: 16 \mathrm{~h} \mathrm{~L}: \mathrm{D}$ (Table 4).

\section{Discussion}

Surprisingly, we observed very low levels of diapause in $A$. ervi after mummy dissections, under all of the photo-thermal regimes tested. As expected, maximum diapause incidence was observed at $8^{\circ} \mathrm{C}, 8: 16 \mathrm{~h} \mathrm{~L}: \mathrm{D}$, which represents conditions typically inducing diapause in aphid parasitoids from temperate areas (Langer \& Hance, 2000; Tougeron et al., 2017b, 2020). However, it concerned only around $25 \%$ of the mummies exposed to these conditions while Christiansen-Weniger and Hardie (1997) observed 100\% diapause induction in fieldcollected populations of $A$. ervi after one generation at $15^{\circ} \mathrm{C}$ and $10: 14 \mathrm{~h} \mathrm{~L}: \mathrm{D}$. The small proportion of diapausing parasitoids we found could be due to the commercial strain of $A$. ervi we used in this experiment and that has been maintained at constant temperatures and photoperiods for several years for mass release by the Viridaxis Company. Under continuous controlled rearing conditions, it is possible that this population has lost a part of its ability to enter diapause (Tougeron et al., 2020). Releasing parasitoids with poor genetic diversity into the fields could impair biological control strategies and long-term establishment of natural enemies, because of low diapause levels and/or low resistance to adverse environmental conditions. Such an observation was already made for Binodoxys communis who showed poor capacity to enter diapause (less than $0.8 \%$ ) and had probably lost that ability due to long period of quarantine rearing (Gariepy et al., 2015). Here we used $8^{\circ} \mathrm{C}$, but probably lower temperature can be more effective and differences among populations are to be expected due 
to local adaptations (Tougeron et al., 2018b).

Mummy characteristics such as coloration or cuticle thickness have been used to discriminate between diapausing and non-diapausing mummies but have not always proved to be reliable (Brodeur \& McNeil, 1989a; Krespi et al., 1994; Polgár et al., 1995; Legrand et al., 2004c). Dark mummies usually show a significant reduction in metabolic rate, which is typical of diapausing insects (Tauber et al., 1986; Hahn \& Denlinger, 2007; Colinet et al., 2010). However, usually few developmental data are available to provide support for this statement, and the reliability of such cue may vary across species. Under temperature and short-day length, we observed higher percentages of dark brown mummies and a clear generational effect on mummy coloration and development timing of $A$. ervi. Our results revealed that at the most autumn-like regime $\left(8^{\circ} \mathrm{C}, 8: 16 \mathrm{~h} \mathrm{~L}: \mathrm{D}\right)$, during 1 st and $2 \mathrm{nd}$ generation, percentage of dark brown mummies was higher as compared to other photothermal regimes. The mummies which were dissected and in which parasitoids were found in diapause were all brown in color. According to Legrand et al. (2004a), change in mummy color could be an adaptation to overwintering, but not necessarily a direct consequence of diapause. In a related aphid parasitoid species, A. rhopalosiphi, dark mummies showed significantly higher water content, survival at low temperature and lower supercooling point values than pale mummies, but the proportion of colored mummies was not linked to diapause induction (Legrand et al., 2004b). Taken together, our results suggest that because the proportion of dark brown colored mummies increased after one generation at $8^{\circ} \mathrm{C} 8: 16 \mathrm{~h}$ L : D, diapause levels could be high. However, as we only found a relatively small proportion of diapausing parasitoids using the dissection method, we cannot fully conclude on the reliability of the mummy coloration method. 
The observed proportion of diapausing mummies, as well as development times, were higher for the $2 \mathrm{nd}$ generation at $8^{\circ} \mathrm{C}, 8: 16 \mathrm{~h} \mathrm{~L}: \mathrm{D}$. In the same way, a generation effect was also observed for the coloration of the mummies with brown mummies more frequent in second generation. Such a potential maternal effect was already reported for instance for Cotesia vestalis (Hao et al., 2013) but also for Trichogramma parasitoids (Voinovich et al., 2015) even on multiple generations (Reznik \& Samartsev, 2015) and is usually observed for mosquitoes (Denlinger \& Armbruster, 2014; Lacour et al., 2014). Adaptive role of TGP and mechanisms facilitating TGP are increasingly becoming elucidated (Mousseau \& Dingle, 1991; Sgrò et al., 2016; Donelson et al., 2018). Conditions perceived by females may influence contents of the egg which acts on the developmental plasticity of the embryo, or act on the next generation through changes in hormonal contents or epigenetic mechanisms (Denlinger, 2002; Uller, 2008; Reynolds, 2017). Such maternal effect would prepare offspring to better face incoming environment, which is known to happen in the natural environment (Mousseau \& Dingle, 1991). Although unlikely to happen under the non-lethal conditions we tested - because selection on diapause can only occur if parasitoids that do not enter diapause die (before reproduction) - non-random mortality at G1 is always possible so phenotypic changes observed within just one generation could either be due to TGP or to selection.

We found a male-biased sex-ratio for all conditions but more pronounced for the most stringent regime. However, it is possible that more females underwent diapause under our experimental conditions and so were part of the individuals that did not emerge rapidly and were dissected at the larval stage. Male biased sex ratios have been reported in some insects emerging from diapause, such as Lucilia caesar L. (Diptera: Calliphoridae) (Ring, 1971) and Asobora tabida Nees (Hymenoptera: Braconidae) (Kraaijeveld \& van Alphen, 1995) and in 
Diprion pini L. (Hymenoptera: Diprionidae) (Geri et al., 1995). Low temperatures are also known to bias sex-ratio in favor of males, which do not require as much resources for their development than females (Langer et al., 2004; Zamani et al., 2007). More recently in A. ervi it was found that females reared at $14{ }^{\circ} \mathrm{C}$ produced more males than females reared at $20{ }^{\circ} \mathrm{C}$ (Tougeron et al., 2020). However, this does not explain why the progeny of $A$. ervi was male biased in our non-diapausing parasitoids. It has been suggested that high male proportion can be linked to laboratory conditions (Heimpel \& Lundgren, 2000).

Time spent in diapause usually induces a higher mortality among diapausing pupae but also decrease egg load, fat reserves, and dry weight of the emerging adult females due to physiological trade-offs (Ellers \& Van Alphen, 1997). Indeed, parasitoids have to deal with limited amount of resources provided by their host. Earlier researches showed such a tradeoff between the resources allocation to reproduction and survival (Ellers \& Van Alphen, 1997; Ellers et al., 2000). In our case, there was a reduction in most of the fitness-related traits in parasitoids exposed to $8^{\circ} \mathrm{C}, 8: 16 \mathrm{~h} \mathrm{~L}: \mathrm{D}$ regime, especially at the second generation. With the increase in development time, the emerging adults were stressed and tibia length was shorter. Although the link between diapause and fitness could only be indirectly assessed, because not all individuals underwent diapause at $8{ }^{\circ} \mathrm{C}, 8: 16 \mathrm{~h} \mathrm{~L}: \mathrm{D}$, our results confirmed that exposure to diapause-inducing cues (photoperiod and temperature combination) has fitness consequences (Zhou et al., 1995; Ismail et al., 2014).

We showed a reduction in size and fresh weight of adults under the $8^{\circ} \mathrm{C}, 8: 16 \mathrm{~h} \mathrm{~L}: \mathrm{D}$ regime for the second generation. Developmental temperature may modulate size of parasitic wasps (Nealis et al., 1984; Bazzocchi et al., 2003; Ichiki et al., 2003) and fitness indicators, such as longevity and fecundity. In addition, fat reserves have been shown to be positively correlated with size and mass (Cloutier et al., 1981; Visser, 1994; Ellers et al., 2001; Frère et 
al., 2011). We have also shown that the longevity of adults was negatively affected by low photoperiod-temperature conditions. These findings can be compared with similar results in the literature (Renault et al., 2002; Colinet et al., 2006; Amice et al., 2008). It is possible that females conserve most of their energy for their fecundity at low temperature, at the expense of their longevity, due to the trade-off longevity-fecundity (Ellers \& Van Alphen, 2002; Michaud \& Qureshi, 2006). We suggest that females invested a part of their fat reserves in fecundity that could have been invested in longevity to resist the effects of cold storage, although egg-load was also negatively affected by low photothermal regimes, at both generations.

It can be predicted that change in phenology through modifications in diapause induction threshold can have dramatic consequences because if the appropriate environmental conditions are not reached, the proportion of individuals that may enter in diapause will be greatly reduced, threatening parasitoid survival in the field. How parasitoids will adapt their seasonal ecology to climate warming and climate unpredictability, and what will be the consequences for aphid-parasitoid interactions and biological control still remain challenging questions (Tougeron et al., 2019). Determining possible changes of threshold levels needed to induce diapause and their consequences on a set of life-history traits of emerging generation are of tremendous importance to better address these issues.

\section{Acknowledgments}

The authors are highly indebted to the Higher Education Commission of Pakistan for providing financial support to Muhammad Mubashir Saeed throughout the study period and the Biodiversity Research Center, Université catholique de Louvain, Belgium for providing the necessary facilities to carry out the research. KT was supported by the F.R.S.-FNRS. The 
authors are also thankful to the anonymous reviewers for their valuable comments that helped to improve the manuscript.

\section{Disclosure}

This paper is part of research publication from the $\mathrm{PhD}$ degree of Muhammad Mubashir Saeed. The author(s) declare that there is no conflict of interest.

\section{References}

Amice, G., Vernon, P., Outreman, Y., Van Alphen, J. and Van Baaren, J. (2008) Variability in responses to thermal stress in parasitoids. Ecological Entomology, 33, 701-708.

Andrade, T.O., Krespi, L., Bonnardot, V., van Baaren, J. and Outreman, Y. (2016) Impact of change in winter strategy of one parasitoid species on the diversity and function of a guild of parasitoids. Oecologia, 180, 877-888.

Basson, C.H., Nyamukondiwa, C. and Terblanche, J.S. (2012) Fitness costs of rapid cold-hardening in Ceratitis capitata. Evolution, 66, 296-304.

Bazzocchi, G.G., Lanzoni, A., Burgio, G. and Fiacconi, M.R. (2003) Effects of temperature and host on the pre-imaginal development of the parasitoid Diglyphus isaea (Hymenoptera: Eulophidae). Biological Control, 26, 74-82.

Bradford, M.J. and Roff, D.A. (1993) Bet hedging and the diapause strategies of the cricket Allonemobius fasciatus. Ecology, 74, 1129-1135.

Brodeur, J. and McNeil, J.N. (1989a) Biotic and abiotic factors involved in diapause induction of the parasitoid, Aphidius nigripes (Hymenoptera: Aphidiidae). Journal of insect Physiology, 35, 969-974.

Brodeur, J. and McNeil, J.N. (1989b) Seasonal microhabitat selection by an endoparasitoid through adaptive modification of host behaviour. Science, 244, 226-228.

This article is protected by copyright. All rights reserved. 
Chidawanyika, F., Mudavanhu, P. and Nyamukondiwa, C. (2020) Global climate change as a driver of bottom-up and top-down factors in agricultural landscapes and the fate of host-parasitoid interactions. Parasitoids' Ecology and Evolution. In press.

Christiansen-Weniger, P. and Hardie, J. (1997) Development of the aphid parasitoid, Aphidius ervi, in asexual and sexual females of the pea aphid, Acyrthosiphon pisum, and the blackberry-cereal aphid, Sitobion fragariae. Entomophaga, 42, 165-172.

Cloutier, C., McNeil, J.N. and Régnière, J. (1981) Fecundity, longevity, and sex ratio of Aphidius nigripes (Hymenoptera: Aphidiidae) parasitizing different stages of its host, Macrosiphum euphorbiae (Homoptera: Aphididae). The Canadian Entomologist, 113, 193-198.

Colinet, H., Hance, T. and Vernon, P. (2006) Water relations, fat reserves, survival, and longevity of a cold-exposed parasitic wasp Aphidius colemani (Hymenoptera: Aphidiinae). Environmental Entomology, 35, 228-236.

Colinet, H., Muratori, F. and Hance, T. (2010) Cold-induced expression of diapause in Praon volucre: fitness cost and morpho-physiological characterization. Physiological Entomology, 35, 301307.

Denlinger, D.L. (2002) Regulation of diapause. Annual Review of Entomology, 47, 93-122.

Denlinger, D.L. and Armbruster, P.A. (2014) Mosquito diapause. Annual Review of Entomology, 59, 73-93.

Donelson, J.M., Salinas, S., Munday, P.L. and Shama, L.N.S. (2018) Transgenerational plasticity and climate change experiments: Where do we go from here? Global Change Biology, 24, 13-34.

Douglas, A. (1998) Nutritional interactions in insect-microbial symbioses: aphids and their symbiotic bacteria Buchnera. Annual Review of Entomology, 43, 17-37.

Ellers, J., Bax, M. and Van Alphen, J.J. (2001) Seasonal changes in female size and its relation to reproduction in the parasitoid Asobara tabida. Oikos, 92, 309-314.

Ellers, J., Driessen, G. and Sevenster, J.G. (2000) The shape of the trade-off function between egg production and life span in the parasitoid Asobara tabida. Netherlands Journal of Zoology, 50, 29-36.

This article is protected by copyright. All rights reserved. 
Ellers, J. and Van Alphen, J.J. (2002) A trade-off between diapause duration and fitness in female parasitoids. Ecological Entomology, 27, 279-284.

Ellers, J. and Van Alphen, J.J.M. (1997) Life history evolution in Asobara tabida: plasticity in allocation of fat reserves to survival and reproduction. Journal of Evolutionary Biology, 10, $771-785$.

Fox, J. and Weisberg, H.S. (2011) An R Companion to Applied Regression, 2nd edn. Sage, Thousand Oaks, CA, USA.

Frère, I., Balthazar, C., Sabri, A. and Hance, T. (2011) Improvement in the cold storage of Aphidius ervi (Hymenoptera: Aphidiinae). European Journal of Environmental Sciences, 1.

Gariepy, V., Boivin, G. and Brodeur, J. (2015) Why two species of parasitoids showed promise in the laboratory but failed to control the soybean aphid under field conditions. Biological Control, $80,1-7$.

Geri, C., Allais, J., Beaudoin, L. and Goussard, F. (1995) Influence of consanguinity on the sex ratio and diapause of Diprion pini L. (Hym., Diprionidae) populations II.-Effect of inbreeding on diapause. Journal of Applied Entomology, 119, 35-43.

Godfray, H.C.J. (1994) Parasitoids: Behavioral and Evolutionary Ecology, Princeton University Press.

Hahn, D.A. and Denlinger, D.L. (2007) Meeting the energetic demands of insect diapause: Nutrient storage and utilization. Journal of Insect Physiology, 53, 760-773.

Hallman, G.J. and Denlinger, D.L. (2019) Temperature Sensitivity in Insects and Application in Integrated Pest Management, CRC Press.

Hance, T., van Baaren, J., Vernon, P. and Boivin, G. (2007) Impact of extreme temperatures on parasitoids in a climate change perspective. Annual Review of Entomology, 52, 107-126.

Hao, Z.P., Tang, B., Chen, C., He, Y.P. and Shi, Z.H. (2013) Maternal effects of photoperiods on glycogen metabolism related to induction of diapause in Cotesia vestalis (Hymenoptera: Braconidae) from Jilin, China. Applied Entomology and Zoology, 48, 47-56. 
Heimpel, G.E. and Lundgren, J.G. (2000) Sex ratios of commercially reared biological control agents. Biological Control, 19, 77-93.

Hodkova, M. and Hodek, I. (2004) Photoperiod, diapause and cold-hardiness. European Journal of Entomology, 101, 445-458.

Hopper, K.R. (1999) Risk-spreading and bet-hedging in insect population biology. Annual Review of Entomology, 44, 535-560.

Ichiki, R., Takasu, K. and Shima, H. (2003) Effects of temperature on immature development of the parasitic fly Bessa parallela (Meigen)(Diptera: Tachinidae). Applied Entomology and Zoology, 38, 435-439.

Ismail, M., van Baaren, J., Briand, V., Pierre, J.S., Vernon, P. and Hance, T. (2014) Fitness consequences of low temperature storage of Aphidius ervi. Biocontrol, 59, 139-148.

Ismail, M., Van Baaren, J., Hance, T., Pierre, J. and Vernon, P. (2013) Stress intensity and fitness in the parasitoid Aphidius ervi (Hymenoptera: Braconidae): temperature below the development threshold combined with a fluctuating thermal regime is a must. Ecological Entomology, 38, $355-363$.

Ismail, M., Vernon, P., Hance, T. and van Baaren, J. (2010) Physiological costs of cold exposure on the parasitoid Aphidius ervi, without selection pressure and under constant or fluctuating temperatures. BioControl, 55, 729-740.

Ismail, M., Vernon, P., Hance, T., Pierre, J.S. and van Baaren, J. (2012) What are the possible benefits of small size for energy-constrained ectotherms in cold stress conditions? Oikos, 121, 20722080.

Jablonka, E. and Raz, G. (2009) Transgenerational epigenetic inheritance: prevalence, mechanisms, and implications for the study of heredity and evolution. The Quarterly Review of Biology, 84, $131-176$.

Kraaijeveld, A.R. and van Alphen, J.J. (1995) Variation in diapause and sex ratio in the parasitoid Asobara tabida. Entomologia Experimentalis et Applicata, 74, 259-265.

This article is protected by copyright. All rights reserved. 
Krespi, L., Dedryver, C.A., Rabasse, J.M. and Nénon, J.P. (1994) A morphometric comparison of aphid mummies containing diapausing vs. non-diapausing larvae of Aphidius rhopalosiphi (Hymenoptera: Braconidae). Bulletin of Entomological Research, 84, 45-50.

Lacour, G., Vernichon, F., Cadilhac, N., Boyer, S., Lagneau, C. and Hance, T. (2014) When mothers anticipate: Effects of the prediapause stage on embryo development time and of maternal photoperiod on eggs of a temperate and a tropical strains of Aedes albopictus (Diptera: Culicidae). Journal of Insect Physiology, 71, 87-96.

Langer, A., Boivin, G. and Hance, T. (2004) Oviposition, flight and walking capacity at low temperatures of four aphid parasitoid species (Hymenoptera: Aphidiinae). European Journal of Entomology, 101, 473-480.

Langer, A. and Hance, T. (2000) Overwintering strategies and cold hardiness of two aphid parasitoid species (Hymenoptera: Braconidae: Aphidiinae). Journal of Insect Physiology, 46, 671-676.

Leather, S.R., Walters, K.F. and Bale, J.S. (1995) The Ecology of Insect Overwintering. Cambridge University Press.

Legrand, M.A., Colinet, H., Vernon, P. and Hance, T. (2004a) Autumn, winter and spring dynamics of aphid Sitobion avenae and parasitoid Aphidius rhopalosiphi interactions. Annals of Applied Biology, 145, 139-144.

Legrand, M.A., Salin, C., Langer, A. and Hance, T. (2004b) Are mummy characteristics reliable indicators of diapause and cold tolerance in the parasitoid wasp Aphidius rhopalosiphi (Braconidae, Aphidiinae)? CryoLetters, 25, 161-166.

Legrand, M.A., Vernon, P., Krespi, L. and Hance, T. (2004c) Morphological and physiological differences between mummy colour morphs of Aphidius rhopalosiphi (Hymenoptera: Braconidae): an adaptation to overwintering? Belgian Journal of Zoology, 134, 9-14.

Levie, A., Vernon, P. and Hance, T. (2005) Consequences of acclimation on survival and reproductive capacities of cold-stored mummies of Aphidius rhopalosiphi (Hymenoptera: Aphidiinae). Journal of Economic Entomology, 98, 704-708.

This article is protected by copyright. All rights reserved. 
Lins, J.C., Bueno, V.H.P., Sidney, L.A., Silva, D.B., Sampaio, M.V., Pereira, J.M., Nomelini, Q.S.S. and Van Lenteren, J.C. (2013) Cold storage affects mortality, body mass, lifespan, reproduction and flight capacity of Praon volucre (Hymenoptera: Braconidae). European Journal of Entomology, 110, 263.

Michaud, J. and Qureshi, J.A. (2006) Reproductive diapause in Hippodamia convergens (Coleoptera: Coccinellidae) and its life history consequences. Biological Control, 39, 193-200.

Mousseau, T.A. and Dingle, H. (1991) Maternal effects in insect life histories. Annual Review of Entomology, 36, 511-534.

Mushegian, A.A. and Tougeron, K. (2019) Host-microbe interactions in the context of diapause. The Biological Bulletin, 237, 180-191.

Nealis, V., Jones, R. and Wellington, W. (1984) Temperature and development in host-parasite relationships. Oecologia, 61, 224-229.

Pigliucci, M. (2006) Phenotypic plasticity and evolution by genetic assimilation. Journal of Experimental Biology, 209, 2362-2367.

Polgár, L.A., Darvas, B. and Völkl, W. (1995) Induction of dormancy in aphid parasitoids: implications for enhancing their field effectiveness. Agriculture, Ecosystems and Environment, 52, 19-23.

Polgár, L.A. and Hardie, J. (2000) Diapause induction in aphid parasitoids. Entomologia Experimentalis et Applicata, 97, 21-27.

Powell, S.J. and Bale, J.S. (2008) Intergenerational acclimation in aphid overwintering. Ecological Entomology, 33, 95-100.

R Core Team (2019) $R$ : A language and environment for statistical computing. $R$ Foundation for Statistical Computing, Vienna, Austria.

Renault, D., Salin, C., Vannier, G. and Vernon, P. (2002) Survival at low temperatures in insects: what is the ecological significance of the supercooling point? Cryoletters, 23, 217-228.

Reynolds, J.A. (2017) Epigenetic Influences on Diapause. Advances in Insect Physiology, Elsevier. 
Reznik, S.Ya. and Samartsev, K.G. (2015) Multigenerational maternal inhibition of prepupal diapause in two Trichogramma species (Hymenoptera: Trichogrammatidae). Journal of Insect Physiology, 81, 14-20.

Ring, R. (1971) Variations in the photoperiodic reaction controlling diapause induction in Lucilia caesar L. (Diptera: Calliphoridae). Canadian Journal of Zoology, 49, 137-142.

Roitberg, B.D., Boivin, G. and Vet, L.E.M. (2001) Fitness, parasitoids, and biological control: an opinion. The Canadian Entomologist, 133, 429-438.

Saunders, D.S. (1965) Larval diapause of maternal origin: induction of diapause in Nasonia vitripennis (Walk.)(Hymenoptera: Pteromalidae). Journal of Experimental Biology, 42, 495508.

Sgrò, C.M., Terblanche, J.S. and Hoffmann, A.A. (2016) What can plasticity contribute to insect responses to climate change? Annual Review of Entomology, 61, 433-451.

Sigsgaard, L. (2000) The temperature-dependent duration of development and parasitism of three cereal aphid parasitoids, Aphidius ervi, A. rhopalosiphi, and Praon volucre. Entomologia Experimentalis et Applicata, 95, 173-184.

Sinclair, B.J., Vernon, P., Jaco Klok, C. and Chown, S.L. (2003) Insects at low temperatures: an ecological perspective. Trends in Ecology and Evolution, 18, 257-262.

Tauber, M.J., Tauber, C.A. and Masaki, S. (1986) Seasonal Adaptations of Insects, Oxford University Press.

Terblanche, J.S., Klok, C.J. and Chown, S.L. (2004) Metabolic rate variation in Glossina pallidipes (Diptera: Glossinidae): gender, ageing and repeatability. Journal of Insect Physiology, 50, $419-428$.

Tougeron, K., Brodeur, J., Le Lann, C. and Van Baaren, J. (2019) How climate change affects the seasonal ecology of insect parasitoids. Ecological Entomology, 45, 167-181.

Tougeron, K., Damien, M., Le Lann, C., Brodeur, J. and Van Baaren, J. (2018a) Rapid responses of winter aphid-parasitoid communities to climate warming. Frontiers in Ecology and Evolution, $6,173$.

This article is protected by copyright. All rights reserved. 
Tougeron, K., Devogel, M., Le Lann, C., Van Baaren, J. and Hance, T. (2020) Trans-generational effects on diapause and life-history-traits of an aphid parasitoid. Journal of Insect Physiology, 121.

Tougeron, K., Hraoui, G., Le Lann, C., Van Baaren, J. and Brodeur, J. (2017a) Intraspecific maternal competition induces summer diapause in insect parasitoids. Insect Science, 25, 1080-1088.

Tougeron, K., Le Lann, C., Brodeur, J. and van Baaren, J. (2017b) Are aphid parasitoids from mild winter climates losing their winter diapause? Oecologia, 183, 619-629.

Tougeron, K., Van Baaren, J., Llopis, S., Ridel, A., Doyon, J., Brodeur, J. and Le Lann, C. (2018b) Disentangling plasticity from local adaptation in diapause expression in parasitoid wasps from contrasting thermal environments: a reciprocal translocation experiment. Biological Journal of the Linnean Society, 124, 756-764.

Travis, J. (1994) Evaluating the adaptive role of morphological plasticity. Ecological Morphology, $99-122$.

Uller, T. (2008) Developmental plasticity and the evolution of parental effects. Trends in Ecology and Evolution, 23, 432-438.

Van Emden, H.F. and Harrington, R. eds. (2017) Aphids as Crop Pests, CABI, Wallingford, UK; Cambridge, MA.

Varpe, Ø. and Ejsmond, M.J. (2018) Trade-offs between storage and survival affect diapause timing in capital breeders. Evolutionary Ecology, 32, 623-641.

Visser, M.E. (1994) The importance of being large: the relationship between size and fitness in females of the parasitoid Aphaereta minuta (Hymenoptera: Braconidae). The Journal of Animal Ecology, 63, 963.

Voinovich, N.D., Reznik, S.Y. and Vaghina, N.P. (2015) Maternal thermal effect on diapause in Trichogramma species (Hymenoptera: Trichogrammatidae). Journal of Applied Entomology, $139,783-790$.

Zamani, A.A., Talebi, A., Fathipour, Y. and Baniameri, V. (2007) Effect of temperature on life history of Aphidius colemani and Aphidius matricariae (Hymenoptera: Braconidae), two 
parasitoids of Aphis gossypii and Myzus persicae (Homoptera: Aphididae). Environmental Entomology, 36, 263-271.

Zhou, X., Honek, A., Powell, W. and Carter, N. (1995) Variations in body length, weight, fat content and survival in Coccinella septempunctata at different hibernation sites. Entomologia Experimentalis et Applicata, 75, 99-107.

Manuscript received January 14, 2020

Final version received April 16, 2020

Accepted April 24, 2020

\section{Tables}

Table 1 Emerging pattern of $A$. ervi adults during 1st and 2nd generation, at different photothermal regimes. Values in brackets are percentages. Total counts of mummies from different colors are displayed. The number of mummies from which nothing emerged after three weeks, the number of mummies from which parasitoids emerged when put back at $16^{\circ} \mathrm{C}$ and the number of dead and alive parasitoids in the remaining mummies are also indicated.

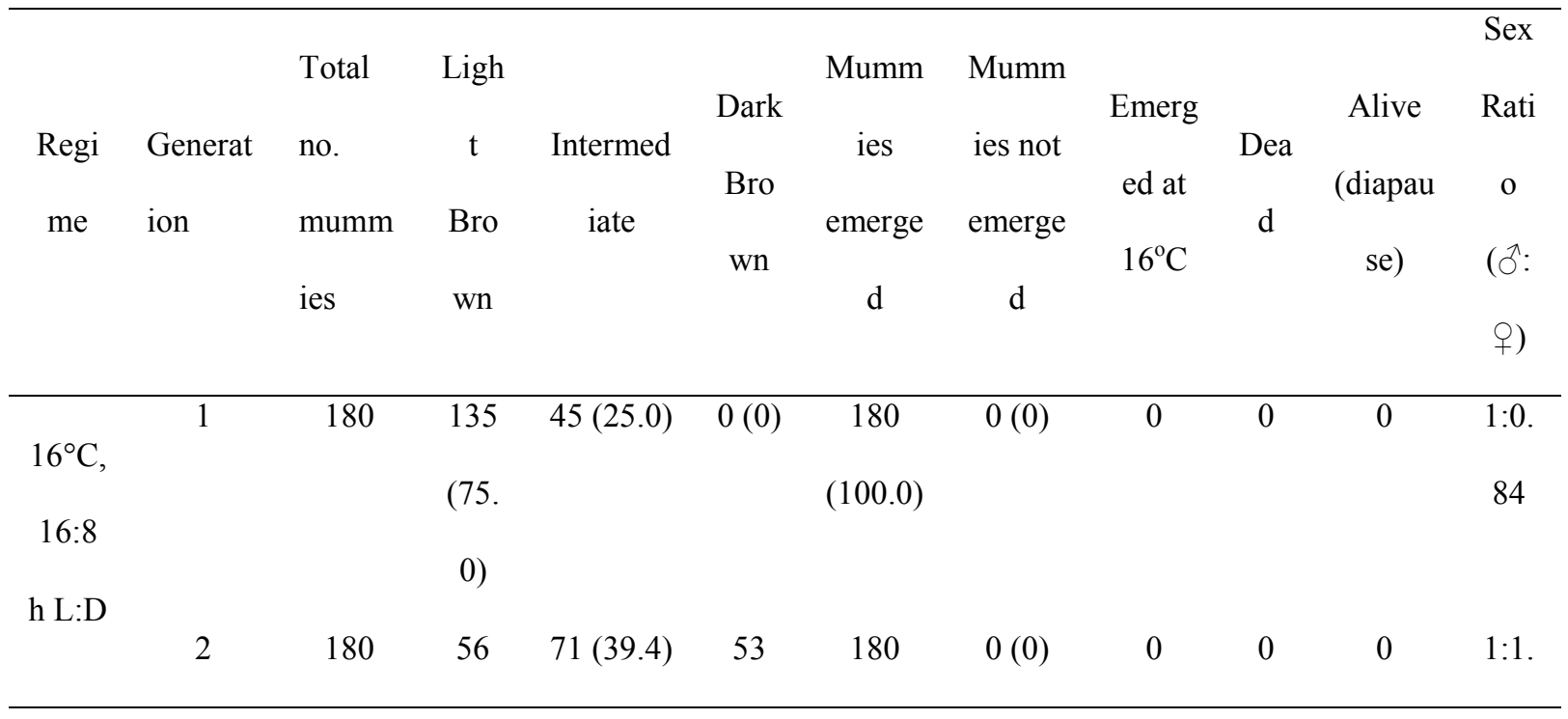




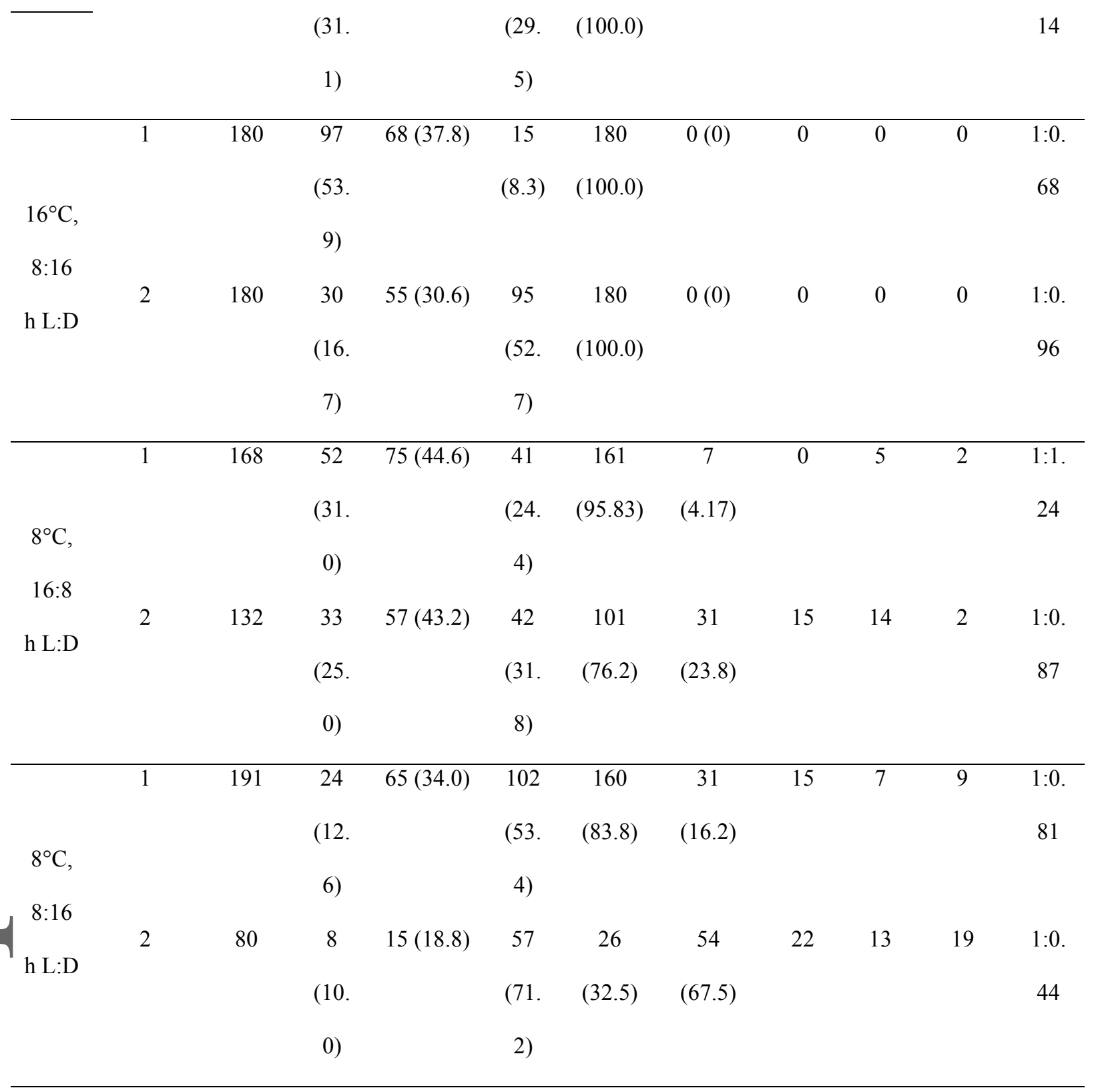


Table 2 Day-degrees necessary for egg-to-mummy and mummy-to-adult development at different photo-thermal regimes

\begin{tabular}{rllll}
\hline \multirow{2}{*}{ Photo-thermal regimes } & \multicolumn{2}{l}{ Egg-Mummy } & \multicolumn{2}{l}{ Mummy-Adult } \\
\cline { 2 - 5 } & $\mathrm{G} 1$ & $\mathrm{G} 2$ & $\mathrm{G} 1$ & $\mathrm{G} 2$ \\
\cline { 2 - 5 } $16^{\circ} \mathrm{C}, 16: 8$ h L:D & 165.6 & 151.8 & 122.2 & 150.4 \\
$16^{\circ} \mathrm{C}, 8: 16 \mathrm{~h} \mathrm{~L}: \mathrm{D}$ & 179.4 & 193.2 & 141 & 197.4 \\
$8^{\circ} \mathrm{C}, 16: 8$ h L:D & 191.4 & 197.2 & 40.6 & 65.8 \\
$8^{\circ} \mathrm{C}, 8: 16 \mathrm{~h} \mathrm{~L}: \mathrm{D}$ & 232 & 243.6 & 92.4 & 121.8 \\
\hline
\end{tabular}

Table 3 Analysis of variance for life history traits for the different treatments. Note that a photothermal regime, as described in the method section, corresponds to a Photoperiod $\times$ Temperature interaction.

\begin{tabular}{|c|c|c|c|c|c|}
\hline Trait & Treatment & & DF & $\operatorname{LR} \chi^{2}$ & $P\left(>\chi^{2}\right)$ \\
\hline \multirow[t]{7}{*}{ Fresh weight } & Photoperiod & & 1 & 0.17 & 0.68 \\
\hline & Temperature & & 1 & 10.45 & $<0.001 * * *$ \\
\hline & Potoperiod $\times$ Temperature & & 1 & 35.59 & $<0.001 * * *$ \\
\hline & Generation & & 1 & 8.87 & $<0.001 * * *$ \\
\hline & Generation $\times$ Photoperiod & & 1 & 0.69 & 0.40 \\
\hline & Generation $\times$ Temperature & & 1 & 0.08 & 0.78 \\
\hline & $\begin{array}{l}\text { Generation } \times \text { Photoperiod } \\
\text { Temperature }\end{array}$ & $\times$ & 1 & 7.69 & $<0.01 * *$ \\
\hline \multirow[t]{7}{*}{ Dry weight } & Photoperiod & & 1 & 15.05 & $<0.001 * * *$ \\
\hline & Temperature & & 1 & 53.57 & $<0.001 * * *$ \\
\hline & Potoperiod $\times$ Temperature & & 1 & 37.47 & $<0.001 * * *$ \\
\hline & Generation & & 1 & 1.66 & 0.20 \\
\hline & Generation $\times$ Photoperiod & & 1 & 2.74 & 0.10 \\
\hline & Generation $\times$ Temperature & & 1 & 1.47 & 0.22 \\
\hline & $\begin{array}{l}\text { Generation } \times \text { Photoperiod } \\
\text { Temperature }\end{array}$ & $x$ & 1 & 0.14 & 0.71 \\
\hline \multirow[t]{7}{*}{ Water contents } & Photoperiod & & 1 & 24.21 & $<0.001 * * *$ \\
\hline & Temperature & & 1 & 39.46 & $<0.001 * * *$ \\
\hline & Potoperiod $\times$ Temperature & & 1 & 8.40 & $<0.01 * *$ \\
\hline & Generation & & 1 & 1.44 & 0.23 \\
\hline & Generation $\times$ Photoperiod & & 1 & 0.46 & 0.50 \\
\hline & Generation $\times$ Temperature & & 1 & 1.51 & 0.22 \\
\hline & $\begin{array}{l}\text { Generation } \times \text { Photoperiod } \\
\text { Temperature }\end{array}$ & $\times$ & 1 & 5.76 & $<0.05 *$ \\
\hline Fat mass & Photoperiod & & 1 & 21.32 & $<0.001 * * *$ \\
\hline
\end{tabular}




\begin{tabular}{|c|c|c|c|c|}
\hline & Temperature & & 12.62 & $<0.001 * * *$ \\
\hline & Potoperiod $\times$ Temperature & & 1.47 & 0.23 \\
\hline & Generation & & 5.03 & $<0.01 * *$ \\
\hline & Generation $\times$ Photoperiod & & 2.72 & 0.09 \\
\hline & Generation $\times$ Temperature & & 1.39 & 0.24 \\
\hline & $\begin{array}{l}\text { Generation } \\
\text { Temperature }\end{array}$ & $\times$ & 0.99 & 0.31 \\
\hline Fat contents & Photoperiod & & 0.003 & 0.9 \\
\hline & Temperature & & 103.5 & $<0.001 * * *$ \\
\hline & Potoperiod $\times$ Temperature & & 14.8 & $<0.001 * * *$ \\
\hline & Generation & & 7.5 & $<0.001 * * *$ \\
\hline & Generation $\times$ Photoperiod & & 12.34 & $<0.001 * * *$ \\
\hline & Generation $\times$ Temperature & & 8.6 & $<0.001 * * *$ \\
\hline & $\begin{array}{l}\text { Generation } \\
\text { Temperature }\end{array}$ & $\times$ & 3.9 & 0.05 \\
\hline Tibia size & Photoperiod & & 90.06 & $<0.001 * * *$ \\
\hline & Temperature & & 0.54 & 0.46 \\
\hline & Potoperiod $\times$ Temperature & & 25.54 & $<0.001 * * *$ \\
\hline & Generation & & 1.71 & 0.19 \\
\hline & Generation $\times$ Photoperiod & & 97.7 & $<0.001 * * *$ \\
\hline & Generation $\times$ Temperature & & 51.4 & $<0.001 * * *$ \\
\hline & $\begin{array}{l}\text { Generation } \times \quad \text { Photoperiod } \\
\text { Temperature }\end{array}$ & $\times$ & 5.40 & $<0.05^{*}$ \\
\hline Longevity male & Photoperiod & & 4.96 & $<0.05 *$ \\
\hline & Temperature & & 437.8 & $<0.001 * * *$ \\
\hline & Potoperiod $\times$ Temperature & & 5.63 & $<0.01 * *$ \\
\hline & Generation & & 76.01 & $<0.001 * * *$ \\
\hline & Generation $\times$ Photoperiod & & 0.90 & 0.34 \\
\hline & Generation $\times$ Temperature & & 6.81 & $<0.05^{*}$ \\
\hline & $\begin{array}{l}\text { Generation } \times \text { Photoperiod } \\
\text { Temperature }\end{array}$ & $\times$ & 9.09 & $<0.05 *$ \\
\hline Longevity female & Photoperiod & & 4.60 & 0.03 \\
\hline & Temperature & & 771.90 & $<0.001 * * *$ \\
\hline & Potoperiod $\times$ Temperature & & 33.91 & $<0.001 * * *$ \\
\hline & Generation & & 50.21 & $<0.001 * * *$ \\
\hline & Generation $\times$ Photoperiod & & 2.56 & 0.11 \\
\hline & Generation $\times$ Temperature & & 33.91 & $<0.001 * * *$ \\
\hline & $\begin{array}{l}\text { Generation } \\
\text { Temperature }\end{array} \quad \times \quad$ Photoperiod & $x$ & 43.52 & $<0.001 * * *$ \\
\hline Egg load & Photoperiod & & 11.1 & $<0.001 * * *$ \\
\hline & Temperature & & 68.6 & $<0.001 * * *$ \\
\hline & Potoperiod $\times$ Temperature & & 7.1 & $<0.001 * * *$ \\
\hline & Generation & & 3.1 & $<0.05^{*}$ \\
\hline & Generation $\times$ Photoperiod & & 0.27 & 0.60 \\
\hline
\end{tabular}

This article is protected by copyright. All rights reserved. 


\begin{tabular}{llllll} 
Generation $\times$ & Temperature & & 1 & 30.96 & $<0.001^{* * *}$ \\
Generation & $\times$ & Photoperiod & $\times$ & 0.1 & 0.80 \\
Temperature & & & 1 & 0.1 & 0 \\
\hline
\end{tabular}

Note regarding to-way interactions including the generation factor: parasitoids from G2 are necessarily coming from the same photoperiod $\mathrm{x}$ temperature regime as those of G1.

Table 4 Mean \pm S.E for life history traits parameters at different photo-thermal regimes.

\begin{tabular}{|c|c|c|c|c|c|c|c|c|c|c|}
\hline \multirow{2}{*}{$\begin{array}{l}\text { Photo- } \\
\text { thermal } \\
\text { regimes }\end{array}$} & \multirow[t]{2}{*}{ Generation } & \multirow{2}{*}{$\begin{array}{l}\text { Fresh weight } \\
(\mathrm{mg})\end{array}$} & \multirow{2}{*}{$\begin{array}{l}\text { Dry } \\
\text { weight } \\
(\mathrm{mg})\end{array}$} & \multirow{2}{*}{$\begin{array}{l}\text { Water } \\
\text { contents }\end{array}$} & \multirow{2}{*}{$\begin{array}{l}\text { Fat } \\
(\mathrm{mg})\end{array}$} & \multirow{2}{*}{$\begin{array}{l}\text { Fat } \\
\text { contents }\end{array}$} & \multirow{2}{*}{$\begin{array}{l}\text { Tibia size } \\
(\mathrm{mm})\end{array}$} & \multicolumn{2}{|c|}{ Longevity (days) } & \multirow[t]{2}{*}{ Egg load } \\
\hline & & & & & & & & Males & Females & \\
\hline $\begin{array}{l}16^{\circ} \mathrm{C}, \\
16: 8 \mathrm{~h} \\
\mathrm{~L}: \mathrm{D}\end{array}$ & 1 & $\begin{array}{l}0.36 \pm 0.11 \\
a b\end{array}$ & $\begin{array}{l}0.09 \pm \\
0.004 \mathrm{a}\end{array}$ & $\begin{array}{l}4.00 \pm \\
0.20 \mathrm{ab}\end{array}$ & $\begin{array}{l}0.030 \pm \\
0.001 \mathrm{a}\end{array}$ & $\begin{array}{l}0.50 \pm 0.03 \\
b\end{array}$ & $\begin{array}{l}0.46 \pm 0.01 \\
d\end{array}$ & $\begin{array}{l}9.6 \pm 0.65 \\
\mathrm{~cd}\end{array}$ & $\begin{array}{l}12.5 \pm \\
0.48 \mathrm{~cd}\end{array}$ & $\begin{array}{l}94.90 \pm 8.11 \\
b\end{array}$ \\
\hline $\begin{array}{l}16^{\circ} \mathrm{C} \\
8: 16 \mathrm{~h} \\
\mathrm{~L}: \mathrm{D}\end{array}$ & 1 & $0.29 \pm 0.01 \mathrm{c}$ & $\begin{array}{l}0.06 \pm \\
0.004 b\end{array}$ & $\begin{array}{l}4.81 \pm \\
0.26 \mathrm{a}\end{array}$ & $\begin{array}{l}0.027 \pm \\
0.002 \mathrm{ab}\end{array}$ & $\begin{array}{l}0.71 \pm 0.06 \\
\mathrm{a}\end{array}$ & $\begin{array}{l}0.64 \pm 0.01 \\
\mathrm{a}\end{array}$ & $\begin{array}{l}11.3 \pm \\
0.54 \mathrm{c}\end{array}$ & $\begin{array}{l}13.9 \pm \\
0.43 \mathrm{c}\end{array}$ & $\begin{array}{l}83.65 \pm 8.30 \\
\text { bc }\end{array}$ \\
\hline $\begin{array}{l}8^{\circ} \mathrm{C}, 16: 8 \\
\text { h L:D }\end{array}$ & 1 & $\begin{array}{l}0.32 \pm 0.01 \\
\mathrm{bc}\end{array}$ & $\begin{array}{l}0.10 \pm \\
0.003 \mathrm{a}\end{array}$ & $\begin{array}{l}3.07 \pm \\
0.07 \mathrm{c}\end{array}$ & $\begin{array}{l}0.025 \pm \\
0.001 \mathrm{abc}\end{array}$ & $\begin{array}{l}0.31 \pm 0.02 \\
\mathrm{~cd}\end{array}$ & $\begin{array}{l}0.56 \pm 0.01 \\
\mathrm{bc}\end{array}$ & $\begin{array}{l}18.2 \pm \\
0.29 \mathrm{a}\end{array}$ & $\begin{array}{l}25.5 \pm \\
0.45 \mathrm{a}\end{array}$ & $\begin{array}{l}92.55 \pm \\
11.21 \mathrm{~b}\end{array}$ \\
\hline $\begin{array}{l}8^{\circ} \mathrm{C}, 8: 16 \\
\text { h L:D }\end{array}$ & 1 & $0.39 \pm 0.01 \mathrm{a}$ & $\begin{array}{l}0.11 \pm \\
0.004 \mathrm{a} \\
\end{array}$ & $\begin{array}{l}3.67 \pm \\
0.12 \mathrm{bc}\end{array}$ & $\begin{array}{l}0.021 \pm \\
0.002 \mathrm{bc}\end{array}$ & $\begin{array}{l}0.24 \pm 0.02 \\
\text { de }\end{array}$ & $\begin{array}{l}0.64 \pm 0.01 \\
\mathrm{ab}\end{array}$ & $\begin{array}{l}17.9 \pm \\
0.28 \mathrm{a}\end{array}$ & $\begin{array}{l}21.8 \pm \\
0.59 \mathrm{~b}\end{array}$ & $\begin{array}{l}43.70 \pm 8.65 \\
\mathrm{~cd}\end{array}$ \\
\hline $\begin{array}{l}16^{\circ} \mathrm{C} \\
16: 8 \mathrm{~h} \\
\mathrm{~L}: \mathrm{D}\end{array}$ & 2 & $\begin{array}{l}0.31 \pm 0.08 \\
\text { bc }\end{array}$ & $\begin{array}{l}0.09 \pm \\
0.003 \mathrm{a}\end{array}$ & $\begin{array}{l}3.49 \pm \\
0.12 \mathrm{bc}\end{array}$ & $\begin{array}{l}0.029 \pm \\
0.001 \mathrm{a}\end{array}$ & $\begin{array}{l}0.49 \pm 0.02 \\
\mathrm{~b}\end{array}$ & $\begin{array}{l}0.58 \pm 0.01 \\
\mathrm{abc}\end{array}$ & $\begin{array}{l}7.6 \pm 0.34 \\
e^{-1}\end{array}$ & $\begin{array}{l}11.8 \pm \\
0.33 \mathrm{~d}\end{array}$ & $\begin{array}{l}145.9 \pm \\
14.19 \mathrm{a}\end{array}$ \\
\hline $\begin{array}{l}16^{\circ} \mathrm{C}, \\
8: 16 \mathrm{~h} \\
\mathrm{~L}: \mathrm{D}\end{array}$ & 2 & $0.29 \pm 0.01 \mathrm{c}$ & $\begin{array}{l}0.07 \pm \\
0.003 \mathrm{~b}\end{array}$ & $\begin{array}{l}4.69 \pm \\
0.29 \mathrm{a}\end{array}$ & $\begin{array}{l}0.019 \pm \\
0.001 \mathrm{c}\end{array}$ & $\begin{array}{l}0.43 \pm 0.03 \\
\mathrm{bc}\end{array}$ & $\begin{array}{l}0.58 \pm 0.01 \\
\mathrm{abc}\end{array}$ & $\begin{array}{l}8.5 \pm 0.31 \\
\text { de }\end{array}$ & $\begin{array}{l}11.8 \pm \\
0.36 \mathrm{~d}\end{array}$ & $\begin{array}{l}146.6 \pm \\
12.38 \mathrm{a}\end{array}$ \\
\hline $\begin{array}{l}8^{\circ} \mathrm{C}, 16: 8 \\
\text { h L:D }\end{array}$ & 2 & $\begin{array}{l}0.31 \pm 0.01 \\
\mathrm{bc}\end{array}$ & $\begin{array}{l}0.09 \pm \\
0.003 \mathrm{a}\end{array}$ & $\begin{array}{l}3.46 \pm \\
0.13 \mathrm{bc}\end{array}$ & $\begin{array}{l}0.024 \pm \\
0.002 \mathrm{abc}\end{array}$ & $\begin{array}{l}0.36 \pm 0.03 \\
\text { bcd }\end{array}$ & $\begin{array}{l}0.54 \pm 0.01 \\
\mathrm{c}\end{array}$ & $\begin{array}{l}14.0 \pm \\
0.39 \mathrm{~b}\end{array}$ & $\begin{array}{l}20.7 \pm \\
0.37 \mathrm{~b}\end{array}$ & $\begin{array}{l}60.85 \pm \\
12.88 \mathrm{bcd}\end{array}$ \\
\hline $\begin{array}{l}8^{\circ} \mathrm{C}, 8: 16 \\
\text { h L:D }\end{array}$ & 2 & $0.25 \pm 0.01 \mathrm{~d}$ & $\begin{array}{l}0.10 \pm \\
0.002 \mathrm{a}\end{array}$ & $\begin{array}{l}3.12 \pm \\
0.10 \mathrm{c}\end{array}$ & $\begin{array}{l}0.018 \pm \\
0.001 \mathrm{c}\end{array}$ & $\begin{array}{l}0.22 \pm 0.02 \\
\mathrm{e}\end{array}$ & $\begin{array}{l}0.49 \pm 0.04 \\
d\end{array}$ & $0.00 \mathrm{f}$ & $0.00 \mathrm{e}$ & $16.30 \pm 8.6 \mathrm{~d}$ \\
\hline HSD & & 0.059 & 0.021 & 0.838 & 0.007 & 0.142 & 0.074 & 1.74 & 1.81 & 47.125 \\
\hline
\end{tabular}

Note: Means sharing similar letters are not statistically significant at $\mathrm{p}=0.05$ among and within generations. 


\section{Figure captions}

Fig. 1. Classes of mummies based on perceived color (cuticle of parasitized aphid containing a L3 larvae/prepupae of $A$. ervi), according to Colinet et al. (2010).

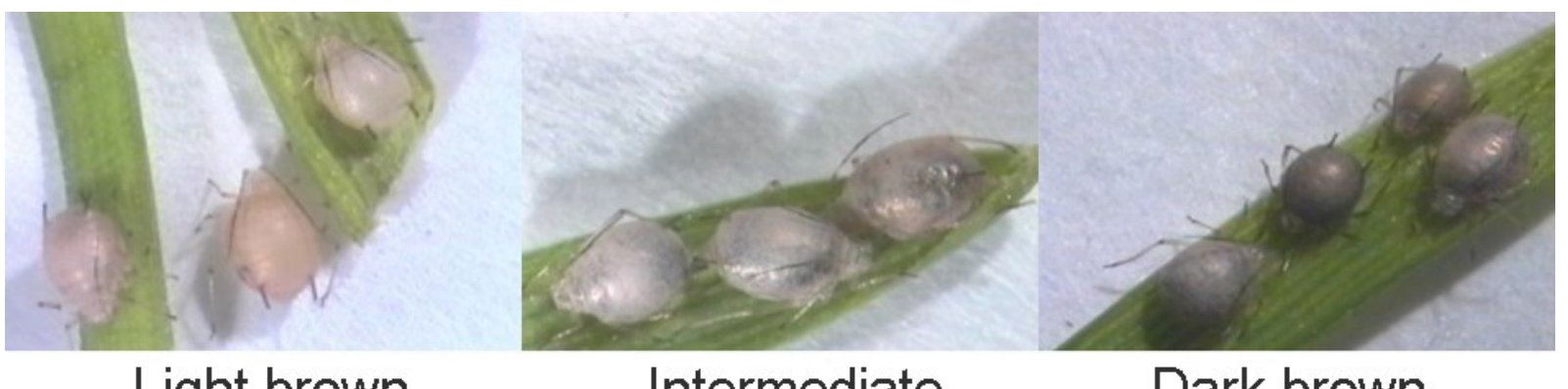

Light brown Intermediate Dark brown

Fig. 2 Percentage of mummies emerged during 1 st and 2 nd generation at different photothermal regimes. $N=1291$ mummies.

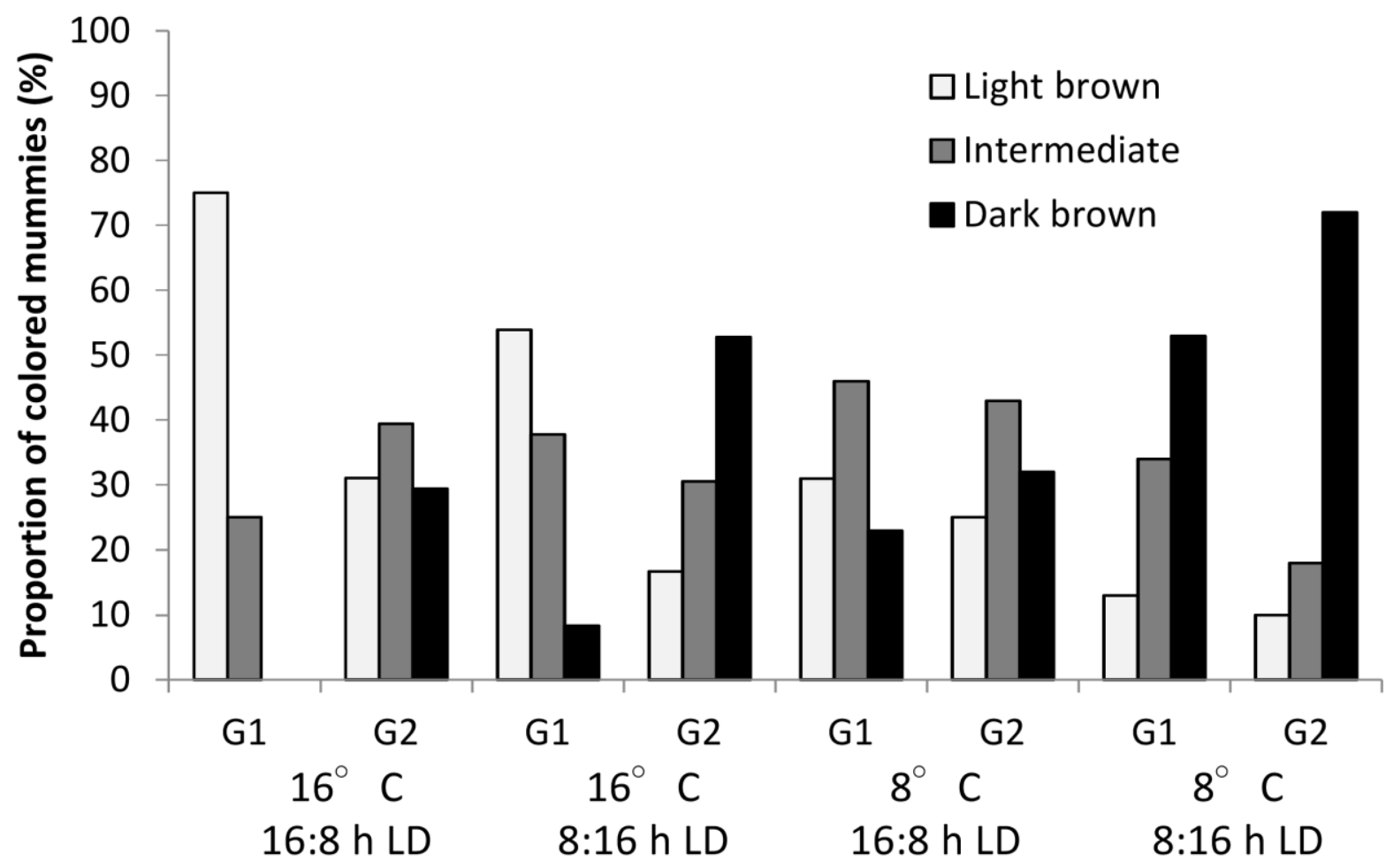


Fig. 3 Emerging pattern of 1st and 2nd generations A. ervi at different photo-thermal regimes. $N=1309$ parasitoids.

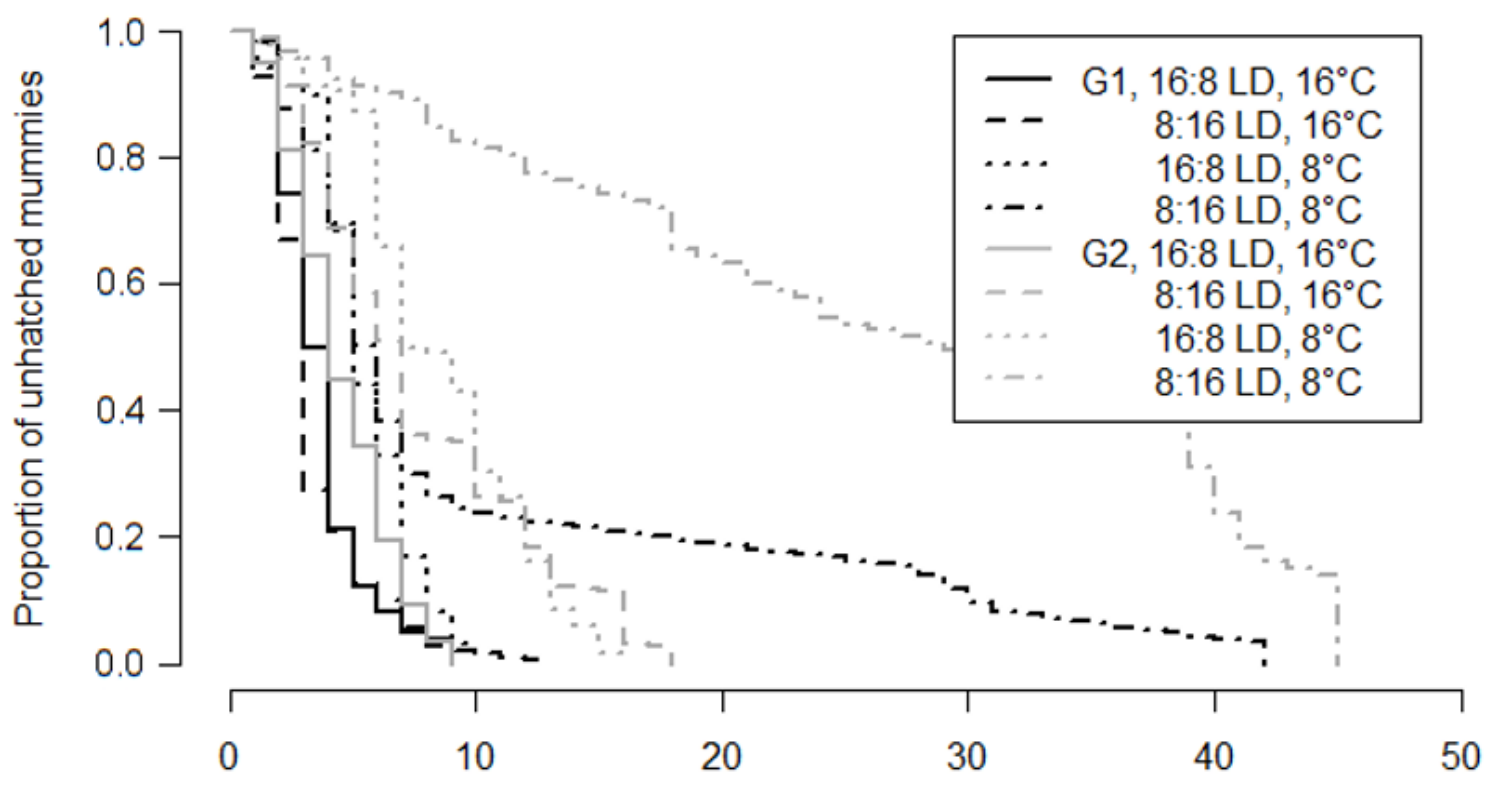

Delay between egg-laying date and adult emergence 